\title{
An Empowerment Tool for Teaching English Effectively to Refugees: A Case Study of Syrian Adult Refugees in the UK
}

\author{
Aisha M. Alhussain ${ }^{1}$ \\ ${ }^{1}$ Princess Nourah University, Riyadh, Saudi Arabia \\ Correspondence: Aisha M. Alhussain, Princess Nourah University, Riyadh, Saudi Arabia. E-mail: \\ amalhusian@pnu.edu.sa
}

Received: October 19, 2018 Accepted: November 26, 2018 Online Published: December 29, 2018

doi:10.5539/ijel.v9n1p389 URL: https://doi.org/10.5539/ijel.v9n1p389

\begin{abstract}
There is a growing demand today to fill the gap in the literature with studies that focus on teaching English to adult refugees who are illiterate or have had interrupted education and no English proficiency. This group has been ignored because ESOL courses are not designed to serve their needs, namely, to be self-reliant and socially integrated. This paper shares my personal experience with six Syrian adult refugees, 2 females and 4 males ranging in age from 26 to 52, with either interrupted elementary education or illiteracy. They had no English language proficiency and could neither speak nor understand English at all. Their first language was Arabic. The rote learning approach was used as an empowerment tool to teach self-reliance in speaking and listening when dealing with these participants' priority themes. The approach is based on memorization using both repetition and recall. Their remarks of progress towards self-reliance varied due to age and motivational factors. Four participants moved from A0 level to A1+, while the other two reached A2 level. Gaining self-reliance helped them to socially integrate, find a job, and gain greater self-confidence. Results of the study might be useful to teachers who are involved in teaching English to refugees as volunteers and to refugees' organizations to shift from relying totally on interpretation to rote learning when specifically dealing with this group of refugees.
\end{abstract}

Keywords: ESOL courses, illiterate adult, rote learning, refugee empowerment and self-reliance, Syrian refugees, teaching English skills

\section{Review of Literature}

Many refugees have left their countries to flee ongoing violence and persecution. Different countries have hosted these refugees, including the United Kingdom, United States, Canada, Australia, and some other Arab countries. The refugees have different educational experiences; some have academic qualifications, but some have not ever attended school. Teaching English to refugees is a vital need because not being able to communicate in English makes refugees feel socially isolated and makes it difficult to find a job to live a more inclusive life in their new country (Hek, 2005; Rutter, 2006; McBrien, 2005). In 2016, the United Kingdom, for instance, announced it would have an extra $£ 10 \mathrm{~m}$ available over five years to teach English to Syrian refugees arriving under the Government Vulnerable Persons Resettlement Scheme (VPRS). There are two key instructional areas when teaching English to refugees: Working with young people for English as an additional language (EAL) and working with adults in English for speakers of other languages (ESOL).

A review of the literature shows that there are several studies on teaching English to refugees. The biggest contribution was found in an essay collection edited by Mallows in 2012 entitled Innovations in English Language Teaching for Migrants and Refugees. It focuses on innovations in Teaching English to migrants and refugees and offers the reader innovative and inspiring experiences of ESOL and EAL teachers who have taught adults and children. These essays discuss educational innovations in primary, secondary, ongoing education, and adult ESOL refugee education. Methods include writing bilingual stories, focusing on vocabulary, raising awareness of the importance of learning the second language and descriptions of how the process occurs. There are stories of migrants and the learning models as well as support received from their schools. These accounts demonstrate the important role schools can play to meet the language needs of refugees. A personal narrative approach is also used to enhance student participation. The teachers' professional development is focused on as an innovation for teaching refugees. A creative ESOL approach using an arts and language program is explored and seen as effective in making students become active in their learning. Emotional support, use of mobile 
technologies, reading circles, and a learner-centered ESOL class are more innovative ideas that are discussed in this volume.

Meyer (2006) criticizes the operation of the Development Assistance for Refugee-hosting areas and its approach (DAR) in Uganda, noting certain flaws that challenge the notion of "empowerment toward self-reliance". She then suggests a full re-examination of the approach to produce better policy for the future. The issue of refugees' language learning, however, is not discussion in her research.

Griffiths (2001) investigates the ESOL course provided to asylum seekers in London and other locations. Barriers to success, such as a shortage of classes and qualified ESOL teachers, a lack of English learning for professional purposes, and funding are highlighted.

Bajwa, et al.'s (2017) qualitative study is an attempt to explore the various educational barriers that face refugees who are interested in obtaining a higher degree in Canada. These include evaluating credentials, funding, and accessing online resources. This study proposes possible solutions that can also be implemented by institutions in Canada.

Rebecca (2005) looked closely at the individual experiences of seven refugees when learning English by following their experience from arrival to the time when the study was conducted. All cases reported in the study were successful due to certain factors, such as using the language outside the classroom, relevance of ESOL lessons to the refugees' day-to-day experiences, learning about the UK culture, and mixing with English speakers.

Warriner's 2007 investigates the relationship between language learning and sense of belonging through exploring the experience of Sudanese women refugees in America. These results were found to be influential for new arrivals especially.

Little's (undated) paper describes the Integrate Ireland Language and Training approach implemented by the Irish government to teach refugees intensive English language. Using that approach, classes are continuous and intensive for one year, and learning and training are integrated. This approach is found to be successful and the outcomes are noticeably fruitful.

Dooley (2009) indicated that many ESL teaching approaches for teaching English as a second language were not effective when teaching refugee students (Sandra \& Taylor 2007) and proposed a different approach based on teaching language alongside actual life content in Australia.

Hans-Jurgen and Plutzar (2008) called for a tailored language program that considers the refugees' linguistic, cultural identities, and life situations and found them to be important factors to achieve successful integration.

Nieuwboer and Rood (2016) proposed an alternative method to support migrant illiterate mothers for social integration. It is socially oriented rather than being only literacy oriented. The focus of this approach is daily and family life, and the results demonstrated progress in both language acquisition and social integration for this group.

Review of related literature shows the urgent demand to address the needs of this ignored group; namely illiterate adult with zero English background refugees through implementing a suitable empowerment tool to teach them English outside class room and encourage them to be self-reliant.

\subsection{Adult Refugees English Learning in the UK}

Learning the local language is important to achieve an inclusion strategy that will enable refugees to become part of the society they have joined, rebuild their lives, and contribute to that society. The government has a key role to play in refugee integration and focuses on teaching English as a vital tool. Unemployed refugees age 19 and older are eligible for an ESOL course. ESOL is an English for Speakers of Other Languages qualification that is provided to refugees who need English in order to communicate in daily life. Adult ESOL is funded by the government like other further education courses in England are. It has five levels, and refugees who apply for British citizenship must reach ESOL Entry Level 3 (House of Commons Library, 2017). In 2016, the Government funded the ESOL program with an additional $£ 10$ million for the delivery of ESOL courses to Syrian Refugees who are under VPRS.

\subsection{A Focus on Syrian Refugees}

The Syrian Vulnerable Persons Resettlement Scheme (VPRS) is intended to resettle 20,000 Syrians in need of protection for a new life in the UK (Home Office, 2017). Syrian refugees are distributed equally across the country, and at least 397 Syrian refugees were resettled in Wales according to figures from the Home Office. Swansea, for instance, welcomed Syrian refugees and supported them in different ways through voluntary and 
charity organizations.

These Syrians used to have high literacy rates, but their schools were considered to be old-fashioned and based on rote learning. Arabic was the teaching language, and English was rarely studied or used. Consequently, Syrian refugees found the transition into a new community harder because they could not speak English and communicate with the locals. Also, some male and female Syrian refugees had not received any formal education at all, but they could still read and write, but in Arabic only. Adult refugees older than 35 with no formal education struggled the most with language and integration into the society. Some were looking for jobs, while others needed to learn how to handle their daily routine needs.

Like other refugees, Syrians are supported by the government and the community as well. Volunteering and charity organizations participate in the refugee support project and offer different services to refugees to fill any gaps in provision, such as case work support, interpretation help, job search, advice and guidance, benefits registration, and any other services badly needed.

\subsection{Volunteering with EYST}

The Ethnic Youth Support Team (EYST) was established in 2005 by ethnic minorities in Swansea and funded by those from the community to deliver education, employment, and health services to ethnic minorities and refugees. From 2017 until 2018, I volunteered with them as an interpreter for the Syrian refugees since my mother tongue is Arabic. The Syrians I served were males and females between 18-52 years old who had only had either interrupted elementary education or no formal education at all. Their arrival date varied from between 3 weeks to one year of the time I met them. Their English language proficiency was zero upon arrival. They were taking ESOL classes, but these classes were not helping them communicate at all, and thus due to their ages, they were at a critical phase of learning (Birdsong, 1999) and had a zero English background. They would call on an interpreter every time they needed to communicate in English. They felt socially isolated and dependent as a result.

\section{Aim of the Study}

The aim of this study is to add to the literature an innovative experience in English language teaching provided to illiterate adult refugees who have not received any formal education and have a zero background in English. ESOL courses do not fit all refugees' needs, and there should be further development to achieve the desired goals of social integration for all refugees and especially adequately support illiterate refugees (Plutzar \& Ritter, 2008). These current ESOL courses focus on in-class teaching with a fixed curriculum and teacher-centered. Differences between native learners and refugee learners and among the refugee learners themselves are too often ignored (Jerks, Bhatia, \& Lou, 2013). Consequently, this group of refugees is unable to run their daily lives and live independently. Instead, they are regularly facing stress and alienation. The method proposed here is an alternative that uniquely focuses on this group and adopts an empowerment approach to help them achieve self-reliance.

\subsection{Empowerment and Self-Reliance}

Empowerment refers to the process of gaining authority and power (Arendt, 1968). This term is implemented in varied forms, including social work, community psychology, economics, law, gender, and workplace management (Rappapon, 2008; Zimmerman, 2000; Potterfield, 1999; Cotula, 2007; Adams, 2008). Olaoye (2013) demonstrated the importance of language as a tool of youth empowerment. He believes that language education can empower Nigerian youth to be able to contribute to national development. According to him, youth can escape poverty and find good jobs and build a bridge to the future through learning the language. Edith (2009) argues that language is a source of empowerment when it is also seen as a tool of authority. The article further points out that an understanding of English is a positive tool to use when accessing knowledge. Indeed, Sankar and Suresh (2016) link English language learning to more employability and empowerment in the business world and other related fields.

Self-reliance is generally defined as the ability to do tasks for yourself to meet your own needs. The word "self-reliance" became a term when it was used as the title of Emerson's Essay in 1841 and it was then mostly used in politics and economics. Meyer (2006) criticized the Self-Reliance Strategy as a program used for refugees in Uganda that caused suffering for those refugees because it entailed dealing with a reduction in food, health care, and needed services. The self -reliance concept, however, was adopted by many language teachers as an end unto itself. It is seen as a characteristic of a good learner who is ready to work independently and take charge of developing needed skills (Ekah, 2012). 


\subsection{Empowerment with Language for Accessing Self-Reliance for Adult Illiterate Syrian Refugees}

I volunteered with EYST from 2017-2018 as an interpreter for those Syrian refugees who came to UK under the VPRS. I served 28 refugees, aged 18-52 years old, both males and females. The literate young Syrian refugees joined the ESOL classes and needed little support in understanding their mail and energy bills, opening bank accounts, writing a CV, and applying for a part-time job, but they learned quickly and started to depend on themselves and rarely asked for support within only 4-6 months, whereas, illiterate older refugees suffered a lot more in different ways as they personally reported.

They reported that they were not benefiting from the ESOL classes because the classes were designed for literates who had some knowledge background and could basically read and write in their mother tongue and have some English background as well. They also complained that important services, such as seeing a doctor or attending a job interview, were delayed due to a shortage of Arabic interpreters and difficulty in traveling to see them. They felt isolated, reliant, and not self-confident. As an English instructor with 30 years' experience in TEFL, I pointed to the vital need to empower refugees with greater English skills outside the classroom to reach the self-reliance stage. This paper discusses applying the rote learning approach to 6 illiterate adult Syrian refugees and traces their stages of improvement and their gains. The duration of the study will be 10 months and focuses on illiterate adult Syrian refugees in Swansea, Wales, UK. It uses their initials in this paper for privacy.

\section{Methodology}

\subsection{Participants}

This paper is a case study, and its participants were six Syrian refugees that I served as an interpreter in Swansea. They included 2 females and 4 males who had either interrupted elementary education or were illiterate. Their ages ranged from 26 -52. They had no English language proficiency and could not speak or understand English at all. Their first language was Arabic.

\subsection{The Cases}

\subsubsection{Case SU}

This 32 year old female Syrian refugee arrived 5 months before I met her. She is married with no children. She had breast cancer and needed regular visits to the breast cancer center. She canceled some of her scheduled visits due to a lack of an interpreter even though her medical condition was critical.

\subsubsection{Case A}

This 39 year old male Syrian refugee arrived 3 months before I met him. He is married with 4 children. He used to work as a painter before moving to the UK. He was looking for a job but speaking English and writing a CV were the main obstacles.

\subsubsection{Case ME (Female)}

This 26 year old female Syrian refugee arrived 4 months before I met her. She is married and recently pregnant. She is not working and is not looking for a job. She needs to see the GP on regular basis and visit the main hospital now and then for an Ultra Sound and blood test as a follow-up.

\subsubsection{Case $\mathrm{H}$}

This 52 year old male Syrian refugee arrived around one year before I met him. His children are grown and self-dependent. He faces problems reading mail, paying bills, contacting the council to report a maintenance issue, shop, and do other daily activities. He used to come from his place by bus to EYST for assistance, and sometimes he is served if there is an available interpreter. Too often he was given an appointment that was often 1-2 weeks in the future, which was very inconvenient and not at all helpful for his needs.

\subsubsection{Case M (Male)}

This 42 year old male Syrian refugee arrived only 2 weeks before I met him. He is married and has 2 boys who attend elementary school. He approached the center for an interpreter to come with him to visit the school and talk about the performance of his boys and help him understand their school reports.

\subsubsection{Case SA}

This 28-year old male Syrian refugee arrived 7 months before I met him. He has been offered a part time job in a small restaurant, but language remains a barrier for him. 


\subsection{Methods and Measurements}

\subsubsection{Rote Learning as an Empowerment Approach}

Contempt for memorization as a learning method is a new attitude, as it is regarded as both old-fashioned and destructive. It is known as rote learning and defined as the memorization of information based on repetition. Rote memorization has its supporters (Iqbal \& Ahmad, 2015; Santrock, 2011) and its opponents (Hilgard, Irvine \& Whipple, 1953; Mayer, 1992). This method has both advantages and disadvantages. Among the advantages are the quick and easy recall of basic facts and development of foundational knowledge. Being repetitive and not allowing for a deeper understanding of knowledge are some of its disadvantages. In contrast, meaningful learning involves a deeper understanding to be long lasting; however, that kind of learning takes longer to achieve, and it has to be specifically tailored to each learner's needs.

In my first month with the participants, I discovered that they had excellent memorization skills and had memorized many verses of the Quran (the Muslim sacred book) since childhood. In this study, the rote learning method was used because first it suited the cases in the sense that it was activating a learning process the participants were familiar with and confident about using. Secondly, the time factor played a vital role with the cases I dealt with and one of the advantages of rote learning is that it is both quick and easy. Some useful features of meaningful learning were implemented too. For instance, the materials used were precisely tailored to serve the urgent and constant needs of the participants. They received explanations of the meaning of related vocabulary and were trained on how to pronounce these words correctly. The process of applying this method took place in different stages as follows:

\section{A. Data collection}

The European Language Portfolio (ELP) for adult migrants learning the language of the host country is partly used in this study. ELP has three components:

- A language passport that provides the learners with language proficiency and qualification;

- A language biography focuses on goals and self-assessment;

- A dossier is a learner portfolio in which the learner keeps samples of work that demonstrate his/her achievement and progress in learning L2. (Little, 2016)

ELP was developed in parallel with the Common European Framework of Reference for Languages (CEFR). It has different types of forms for teachers to use with immigrants (Simpson, 2012). Due to the A0 level of these participants' English language proficiency, all the forms used were translated into Arabic and filled in by the researcher because not all the participants could read or write in Arabic. Two forms from the language passport component were used in this study: My personal identity form (see Appendix A.) and my learning and linguistic identity (see Appendix B.). These two forms were used to collect details about the participants, such as name, address, email, future work, nationality, etc., and assess their L2 proficiency. They were also translated into Arabic because the participants could not understand them (see Table 1 and Table 2).

Table 1. Personal details of the participants

\begin{tabular}{llllllllll}
\hline Name & Age & Gender & Nationality & Occupation & Arrival & Work done & Studies done & Targeted work & Targeted study \\
\hline SU & 32 & F & Syrian & No work & $5 \mathrm{~ms}$ & Housewife & illiterate & No & No \\
A & 39 & M & Syrian & No work & $3 \mathrm{~ms}$ & Painter & interrupted & Painter & No \\
ME & 26 & F & Syrian & No work & $4 \mathrm{~ms}$ & Housewife & illiterate & No & No \\
H & 52 & M & Syrian & No work & $1 \mathrm{yr}$ & Mechanic & illiterate & No & No \\
M & 42 & M & Syrian & No work & $2 \mathrm{ws}$ & Carpenter & illiterate & Carpenter & No \\
SA & 28 & M & Syrian & No work & $7 \mathrm{~ms}$ & Waiter & interrupted & Waiter & No \\
\hline
\end{tabular}

Table 2. Linguistic identities of the participants

\begin{tabular}{llllll}
\hline Name ID & Language & Speak & Listen & Read & Write \\
\hline SU & Arabic & Y & Y & Quran only & N \\
A & Arabic & Y & Y & Y & Y \\
ME & Arabic & Y & Y & Quran only & N \\
H & Arabic & Y & Y & Quran only & N \\
M & Arabic & Y & Y & Quran only & N \\
SA & Arabic & Y & Y & Y & Y \\
\hline
\end{tabular}


On the language biography component, Part 1 was used to identify the learner's learning priority and self-assessment for L2 learning (Appendix C.). See Table 3 below

Table 3. First self-assessment of learning (language)

\begin{tabular}{lllllll}
\hline Name & $\begin{array}{l}\text { Can express } \\
\text { my } \\
\text { in English }\end{array}$ & $\begin{array}{l}\text { Can answer } \\
\text { questions in } \\
\text { English }\end{array}$ & $\begin{array}{l}\text { Can explain things } \\
\text { in English }\end{array}$ & $\begin{array}{l}\text { Can speak on the } \\
\text { telephone } \\
\text { English }\end{array}$ & $\begin{array}{l}\text { Can understand } \\
\text { in } \\
\text { documents that I } \\
\text { read in English }\end{array}$ & $\begin{array}{l}\text { Can fill in forms and } \\
\text { write messages }\end{array}$ \\
\hline SU & No & No & No & No & No & No \\
A & No & No & No & No & No & No \\
ME & No & No & No & No & No & No \\
H & No & No & No & No & No & No \\
M & No & No & No & No & No & No \\
SA & No & No & No & No & No & No \\
\hline
\end{tabular}

Another form used from the ELP was the priorities form (see Appendix D.). Here the participants' themes they believed were important to learn and their reasons for choosing these themes were recorded. They were encouraged to add other themes if those were not included in the form (see Table 4).

Table 4. Participants' learning priorities

\begin{tabular}{lll}
\hline Name & Theme & Reason/Purpose \\
\hline SU & Health and hospital & To visit the breast cancer center for follow-up and regular check-ups \\
A & Work and occupation & To get a job as a painter \\
ME & Health and hospital & To see the Gynecologist to follow up on pregnancy \\
$\mathbf{H}$ & Dealing with officials/shopping/daily activities & To read mail, pay bills, contact the Council to report a maintenance issue \\
$\mathbf{M}$ & Children's education & To visit school and talk about the performance of his children and understand \\
& & school reports. \\
SA & Work and occupation & To work as a waiter in a restaurant \\
\hline
\end{tabular}

\section{B. Assessment tools}

The CEFR assessment grid was used as the tool to assess the participants' level of proficiency in speaking and listening only (see Appendix E.) (CEFR; Council of Europe, 2001). This grid was slightly adjusted to measure the proficiency and progress for the participants' priority themes. The A1 and A2 checklists for speaking and listening with some adjustments to suit the identified themes were used (see Appendices F \& G) to trace the progress of the participants (Little, 2012).

C. Materials

After identifying the priority themes of the participants and interpreting for them 3-4 times every two weeks, the need to customize suitable materials became apparent. The topics were specified, and their content was designed to have simple short sentences and easy vocabulary in order to serve the participants' needs and proficiency levels well. The content was also compiled to serve the following learning targets:

Table 5. Learning targets

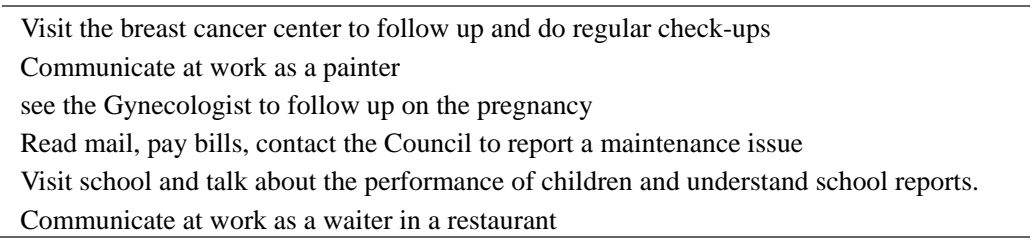

For each topic, there were subtitles. For instance, to visit the cancer center, there was the introductory part where the patient had to give her personal details, her medical history, and the reason for the visit. The second part was about routine medical investigations, such as blood screening, mammogram, Ultra Sound, taking a biopsy etc. The third part was about the follow-up visit to get results and get another appointment and medication as well as a treatment plan. Working as a painter involves using different paint colors and shades; naming furniture and 
their parts; negotiating prices; and handling problems and complaints.

D. Rote learning implementation

This learning process took place gradually as follows:

Observation: In this stage the participant was asked to observe me while I was interpreting to get a general idea about the issues being dealt with and how to answer them. It lasted from 2-3 visits;

Recording: Here all possible questions and answers related to the target theme were recorded in my voice in English and Arabic on their mobile phones for each part and separately to avoid confusion;

Memorizing: The answers were recalled by repeating them several times and understanding the questions;

Recalling: Being able to give the answers by heart;

Repeating, memorizing, and recalling;

Allowing the participant to take a small part in the task being performed to answer some of the easy questions, for instance;

Once the first part was memorized and mastered, the participant moved to the second part with more self-confidence and self -reliance while at the same time still recalling the first part;

New vocabulary: It was gradually introduced, and only easy words and simplified sentences were used;

The process took ten months, excluding holidays and weekends.

\section{Results and Discussion}

Progress check lists for listening and speaking were used with each theme to record participants' progress. The results were scored, analyzed, and reflected in Table 6 below.

Table 6. CEFR band participants’ progress in listening and speaking

\begin{tabular}{lll}
\hline Name & Baseline & Final level after 12 months \\
\hline SU & A0 & A1+ \\
A & A0 & A1+ \\
ME & A0 & A2 \\
H & A0 & A1 \\
M & A0 & A1+ \\
SA & A0 & A2 \\
\hline
\end{tabular}

A progress line was drawn to demonstrate the effect of the rote learning as an empowerment tool for achieving self-reliance (see Table 7)

Table 7. Participants’ progress line

\begin{tabular}{|c|c|c|c|c|c|}
\hline Name & Skills & A0 & A1 & A1+ & A2 \\
\hline \multirow[t]{2}{*}{ SU } & Listening & - & & & + \\
\hline & Speaking & - & & & + \\
\hline \multirow[t]{2}{*}{ A } & Listening & - & & & + \\
\hline & Speaking & - & & & + \\
\hline \multirow[t]{2}{*}{ ME } & Listening & - & & & + \\
\hline & Speaking & - & & & + \\
\hline \multirow[t]{2}{*}{ H } & Listening & - & & & + \\
\hline & Speaking & - & & & + \\
\hline \multirow[t]{2}{*}{ M } & Listening & - & & & + \\
\hline & Speaking & - & & & + \\
\hline \multirow[t]{2}{*}{ SA } & Listening & - & & & + \\
\hline & Speaking & - & & & + \\
\hline
\end{tabular}

Several progress remarks and the evidences for each participant were pointed out. SU's listening and speaking skills improved when dealing with her theme, which related to her health condition (see Table 8). 
Table 8. Participant SU's progress

\begin{tabular}{lllll}
\hline Name & Skills & A0 & A1 & A1+ \\
\hline SU & Listening & $\begin{array}{l}\text { She cannot } \\
\text { understand anything } \\
\text { in English }\end{array}$ & $\begin{array}{l}\text { She understands the familiar words } \\
\text { about her personal details and some } \\
\text { words about her medical history }\end{array}$ & $\begin{array}{l}\text { She understands simple sentences when people } \\
\text { speak slowly and clearly and understands the } \\
\text { doctor and nurse's simple instructions }\end{array}$ \\
\cline { 2 - 5 } & Speaking & $\begin{array}{l}\text { She cannot speak any } \\
\text { English }\end{array}$ & $\begin{array}{l}\text { She can give answers from one to two } \\
\text { words about her personal details and } \\
\text { about her medical condition }\end{array}$ & $\begin{array}{l}\text { She can produce full simple sentences about } \\
\text { her personal details and medical condition and } \\
\text { can ask short questions about a procedure and } \\
\text { her next appointment }\end{array}$ \\
\end{tabular}

SU showed progress in listening and speaking skills as well as in achieving self-reliance. At the beginning, she had no self-confidence to speak, but after some time and more encouragement and explaining her urgent need to be self-reliant to save effort and money, she started to gradually interact. Her health condition was a motivating factor for her to memorize and recall the vocabulary and the sentences especially designed for her theme and produce them in a later stage.

Table 9. Participant A’s progress

\begin{tabular}{lllll}
\hline Name & Skills & A0 & A1 & A1+ \\
\hline A & Listening & $\begin{array}{l}\text { He cannot understand } \\
\text { anything in English }\end{array}$ & $\begin{array}{l}\text { He understands the familiar words about } \\
\text { paint shades and some words about } \\
\text { furniture }\end{array}$ & $\begin{array}{l}\text { He understands simple sentences when people } \\
\text { speak slowly and clearly and understands } \\
\text { clients' requests and instructions }\end{array}$ \\
\cline { 2 - 6 } & Speaking & $\begin{array}{l}\text { He cannot speak any } \\
\text { English }\end{array}$ & $\begin{array}{l}\text { He can give answers from one to two } \\
\text { words about his previous experience as a }\end{array}$ & $\begin{array}{l}\text { He can produce full simple sentences about his } \\
\text { previous and current work experience and can } \\
\text { interact with clients about painting furniture }\end{array}$ \\
& & $\begin{array}{l}\text { painter and can produce broken sentences } \\
\text { related to his job as a painter }\end{array}$ & \\
\hline
\end{tabular}

Participant A started working in a small charity shop where he interacted only with the supervisor. After gaining greater self-confidence, he started to deal directly with the clients. A was motivated by his need for a job to earn money and provide his family their previous standard of living before the war in Syria. He has reported lately that he is now self-reliant and not calling for an interpreter like he did before. When I first met him, he was not able to write his $\mathrm{CV}$, but now he is directing his friends on how to do it based on his own version.

Table 10. Participant ME’s progress

\begin{tabular}{lllll}
\hline Name & Skills & A0 & A1 & A2 \\
\hline ME & Listening & $\begin{array}{l}\text { She cannot } \\
\text { understand } \\
\text { anything in } \\
\text { English }\end{array}$ & $\begin{array}{l}\text { She can understand the familiar words } \\
\text { concerning pregnancy and understand } \\
\text { short sentences about simple short }\end{array}$ & $\begin{array}{l}\text { She can understand full sentences related to her medical } \\
\text { condition and understand types of blood screenings and } \\
\text { can understand the doctor's short, clear explanation } \\
\text { medical instructions }\end{array}$ \\
\cline { 2 - 6 } & Speaking & $\begin{array}{l}\text { She cannot } \\
\text { speak any }\end{array}$ & $\begin{array}{l}\text { She can use simple sentences to answer } \\
\text { short questions on personal details and }\end{array}$ & $\begin{array}{l}\text { She can interact and produce full simple sentences to } \\
\text { describe simple symptoms and ask short questions about } \\
\end{array}$ \\
& English & when describing symptoms & blood screening results or ultrasound pictures \\
\hline
\end{tabular}

Participant ME achieved a higher progress rate when compared to the other participants. That might be due to her young age, as learning another language and memorizing was faster (Fathman, 2006; Tohidian, 2009).ME was also highly motivated as a new mom who was eager to learn and know everything about her new baby.

Table 11. Participant H’s progress

\begin{tabular}{llll}
\hline Name & Skills & A0 & A1 \\
\hline $\mathbf{H}$ & Listening & $\begin{array}{l}\text { He cannot understand } \\
\text { anything in English }\end{array}$ & $\begin{array}{l}\text { He can understand some familiar words concerning mail, paying bills, } \\
\text { contacting the Council to report a maintenance issue, and he can } \\
\text { understand very short and simple sentences related to his priority theme }\end{array}$ \\
\cline { 2 - 4 } & Speaking & $\begin{array}{l}\text { He cannot speak any } \\
\text { English }\end{array}$ & $\begin{array}{l}\text { He can use simple broken sentences to answer short questions on } \\
\text { personal details and when reporting a related issue }\end{array}$ \\
\hline
\end{tabular}


$\mathrm{H}$ showed slow progress due to his age and poor memory. He kept memorizing things repeatedly, but then struggled with recalling them. $\mathrm{H}$ achieved partial self-reliance in the sense that he started to make fewer visits to the center to seek translation support.

Table 12. Participant M’s progress

\begin{tabular}{lllll}
\hline Name & Skills & A0 & A1 & A1+ \\
\hline $\mathbf{M}$ & Listening & $\begin{array}{l}\text { He cannot understand } \\
\text { anything in English }\end{array}$ & $\begin{array}{l}\text { He can understand familiar words about } \\
\text { his boys' grades, subjects, school } \\
\text { activities, and marks. }\end{array}$ & $\begin{array}{l}\text { He can understand simple sentences when he } \\
\text { interacts with teachers if they speak slowly } \\
\text { and clearly }\end{array}$ \\
\cline { 2 - 5 } & Speaking & $\begin{array}{l}\text { He cannot speak any } \\
\text { English }\end{array}$ & $\begin{array}{l}\text { He can give short answers about his } \\
\text { boys' progress and report problems in } \\
\text { broken sentences }\end{array}$ & $\begin{array}{l}\text { He can produce full simple sentences about his } \\
\text { boys' school reports and school activities }\end{array}$ \\
\hline
\end{tabular}

Being a single dad was a learning motivator for this participant to progress and reach self-reliance. It was very difficult for him to find an interpreter on the same day of the parents' gatherings, so he often missed them, but now he can go alone and talk to the teachers by himself.

Table 13. Participant SA's progress

\begin{tabular}{lllll}
\hline Name & Skills & A0 & A1 & A2 \\
\hline SA & Listening & $\begin{array}{l}\text { He cannot } \\
\text { understand anything } \\
\text { in English }\end{array}$ & $\begin{array}{l}\text { He can understand familiar words related to } \\
\text { working in a restaurant and can understand } \\
\text { short sentences when talking to clients }\end{array}$ & $\begin{array}{l}\text { He can understand full sentences } \\
\text { related to taking orders and clients } \\
\text { other requests }\end{array}$ \\
\cline { 3 - 6 } & Speaking & $\begin{array}{l}\text { He cannot speak any } \\
\text { English }\end{array}$ & $\begin{array}{l}\text { He can produce short questions and answers } \\
\text { when dealing with clients and can name the } \\
\text { different items in the restaurant }\end{array}$ & $\begin{array}{l}\text { He can interact and produce full } \\
\text { simple sentences that related to his job } \\
\text { as a waiter }\end{array}$ \\
\hline
\end{tabular}

Fast progress in SA's self -reliance was noted and that might due to his age and language immersion. He practiced the language intensively with native speakers and interacted with the co -workers in English.

\section{Conclusion}

The need to support illiterate refugees or those with interrupted education who have no English language proficiency is vital because their need for greater self-reliance is too often ignored. The fact that the currently designed ESOL courses do not meet their urgent needs and do not take into consideration their language and education levels and do not give them the opportunity to practice the language outside classrooms, makes finding a suitable strategy an important demand.

This study clearly adds to the literature an innovative practice for practical experience in English Language teaching to those illiterate adult refugees who have not received formal education and have a zero English background. The study activates a traditional method of learning called rote learning, which is based on memorizing and recalling. The participants were six adult Syrian refugees, illiterate or with interrupted education and with no English language proficiency.

The results showed progress in the participants' speaking and listening ability when dealing with their priority themes. All reported needing less reliance on interpreters and demonstrating more self-reliance that saved them both time and effort in their new environments.

\section{References}

Adams, R. (2008). Empowerment, participation and social work. New York: Palgrave Macmillan. https://doi.org/10.1007/978-1-137-05053-3

Arendt, H. (1986). Communicative power. In S. Lukes (Ed.), Power (pp. 59-74). Oxford: Basil Blackwell.

Bajwa, J., Couto, S., Kidd, S., Markoulakis, R., Abai, M., \& Mckenzie, K. (2017). Refugees, higher education, and informational barriers. Refuge, 33(2), 56-65.

CEFR. Accessed Feburary 6, 2018. http://www.coe.int/t/dg4/linguistic/cadre1 en.asp.

Cotula, L. (2007). Legal empowerment for local resource control. Hertfortshire: Russell Press. 
Dooley, K. (2009). Rethinking pedagogy for middle school students with little, no or severely interrupted schooling. English Teaching: Practice and Critique, 8(1), 5-22.

Ekah, E. (2012). Regenerating English language teaching in Nigeria for self-reliance and national development. Journal of Resourcefulness and Distinction, 4(1), 109-120.

Emerson, R. (1982). Selected essays. Harmondsworth: Penguin American Library.

Esch, E. (2009). English and empowerment: Potential, issues, way forwards. In N. Hussain, A. Azar, \& M. Zafar (Eds.), English and empowerment in the developing world (pp. 2-12). Newcastle: Cambridge Scholars Publishing.

Fathman, A. (2006). The relationship between age and second language productive ability. Language Learning, 25(2), 245-253. https://doi.org/10.1111/j.1467-1770.1975.tb00244.x

Griffiths, D. (2001). English language training for refugees in London and the regions. London: the research development and statistics directorate, Home Office. Retrieved from http://webarchive.nationalarchives.gov.uk/20110218141521/http://rds.homeoffice.gov.uk/rds/pdfs2/rdsolr14 03.pdf

Hans-Jurgen, K., \& Plutzar, V. (2008). Tayloring language provision and requirements to the needs and capacities of adult migrants. June 26-27. Retrieved from http://www.coe.int/t/dg4/linguistic/MigrantsSemin08_ListDocs_EN.asp\#TopOfPage

Hek, R. (2005). The experiences and needs of refugee and asylumseeking children in the UK: A literature review. Birmingham: National Evaluation of the Children's Fund.

Hilgard, E., Irvine, R., \& Whipple, J. (1953). Rote memorization, understanding, and transfer: An extension of Katona's card-trick experiments. Journal of Experimental Psychology, 46(4), 288-292. https://doi.org/10.1037/h0062072

Iman, T. (2009). Effects of age on second language aquisition. California Linguistic Notes, XXXIV, 1-6.

Iqbal, J., \& Ahmad, A. (2015). Effect of extensive rote learning experience on subsequent academic achievement. Pak Armed Forces Med, 65(4), 510-14.

Jerks, C., Bhatia, A., \& Lou, J. (2013). The discourse of culture and identity in national and transnational context. $\begin{array}{llll}\text { Language and intercultural communication, } & 13(2),\end{array}$ https://doi.org/10.1080/14708477.2013.770862

Little, D. (2012). The linguistic integration of adult migrants and the European language portfolio: an introduction. Council of Europe. Retrieved http://www.ismu.org/wp-content/uploads/2015/02/LIAM-ELP_Introduction_EN.pdf

Little, D. (2016). The linguistic integration of adult migrants and the European language portfolio: goal-setting and self-assessment checklists. Retrieved from http://rm.coe.int/CoERMPublicCommonSearchServices/DisplayDCTMContent?documentId=09000016802 fc1cc

Little, D. (n.d.). Responding to the language needs of adult refugees in Ireland: an alternative approach to teaching and assessment. from http://www.coe.int/t/dg4/linguistic/source/Little_IILT_CS_Migrants_EN.doc

Mallows, D. (2012). Inovations in English language teaching for migrants and refugees. British council. Retrieved from https://englishagenda.britishcouncil.org/continuing-professional-development/teacher-educator-framework/ understanding-teaching-context/innovations-english-language-teaching-migrants-and-refugees

Mayer, R. (1992). Thinking, problem solving, cognition. New York: Freeman.

MCBrien, J. (2005). Educational needs and barriers for refugee students in the United States: A review of the literature. Review of Educational Research, 75(3), 329-364. https:// doi.org/ 10.3102/00346543075003329

Meyer, S. (2006). The refugee aid and development approach in Uganda: Empowerment and self-reliance of refugees in practice. Working paper No.131, Geneva: UNHCR Evaluation and Policy Analysis Unit. Retrieved from http://www.unhcr.org/uk/4538eb172.pdf

Nieuwboer, C., \& Rood, R. (2016). Learning language that matters A pedagogical method to support migrant mothers without formal education experience in their social integration in Western countries. International 
Journal of Intercultural Relations, 51, 29-40. https://doi.org/10.1016/j.ijintrel.2016.01.002

Nieuwboer, C., \& Vant, R. R. (2016). Progress in proficiency and participation: an adult learning approach to support social integration of migrants in western societies. In J.-C. Beacco, D. Little, P. Thalgott, \& H.-J. Krumm (Eds.), The linguistic integration of adult migrants: some lessons from research (pp. 201-206). De Gruyter Mouton.

Olaoye, A. (2013). Language education and youth empowerment: A linguistic strategy for achieving Nigeria's Millennium development goals. Theory and Practice in language Studies 1946-1951. https://doi.org/10.4304/tpls.3.11.1946-1951

Plutzar, V., \& Ritter, M. (2008). Language learning in the context of migration and integration-challanges and options for adult learners. Retrieved from https://rm.coe.int/CoERMPublicCommonSearchServices/DisplayDCTMContent?documentId=0900001680 2fc1d6

Potterfield, T. (1999). The business of employee empowerment: Democracy and ideology in the workplace. Westport: Greenwood Publishing Group.

Rappapon, J. (2008). Studies in empowerment:Introduction to the issue. Prevention in Human Services, 3(2-3), 1-7. https://doi.org/10.1300/J293v03n02_02

Rebecca, T. (2005). Forced migrants success with English language learning in the UK. Retrieved from www.forcedmigrantslanguagelearning.pwp.blueyonder.co.uk

Rutter, J. (2006). Refugee children in the UK. Berkshire: Open University Press.

Sandra, R., \& Taylor, S. (2007). Educational provision for refuhee youth in Australia: left to chance? Journal of Sociology, 43(3), 283-300. https://doi.org/10.1177/1440783307080107

Sankar, G., \& Suresh, S. (2016). English for employment and empowerment: A study. International Journal of English Literature and Culture, 4(6), 100-103. https://doi.org/10.14662/IJELC2016.053

Santrock, J. (2011). Educational Psychology. New York: McGraw-Hill.

Warriner, D. (2007). Language learning and the politics of belonging:Swdanese women refugees becoming and being “American”. Anthropology and Education, 38(4), 343-359. https://doi.org/10.1525/aeq.2007.38.4.343

Zimmerman, M. (2000). Empowerment theory: Psychological, organizational and community levels of analysis. In J. Rappaport \& E. Seidman (Eds.), Handbook of community psychology (pp. 43-63). Boston: Springer. https://doi.org/10.1007/978-1-4615-4193-6_2 
Appendix A.
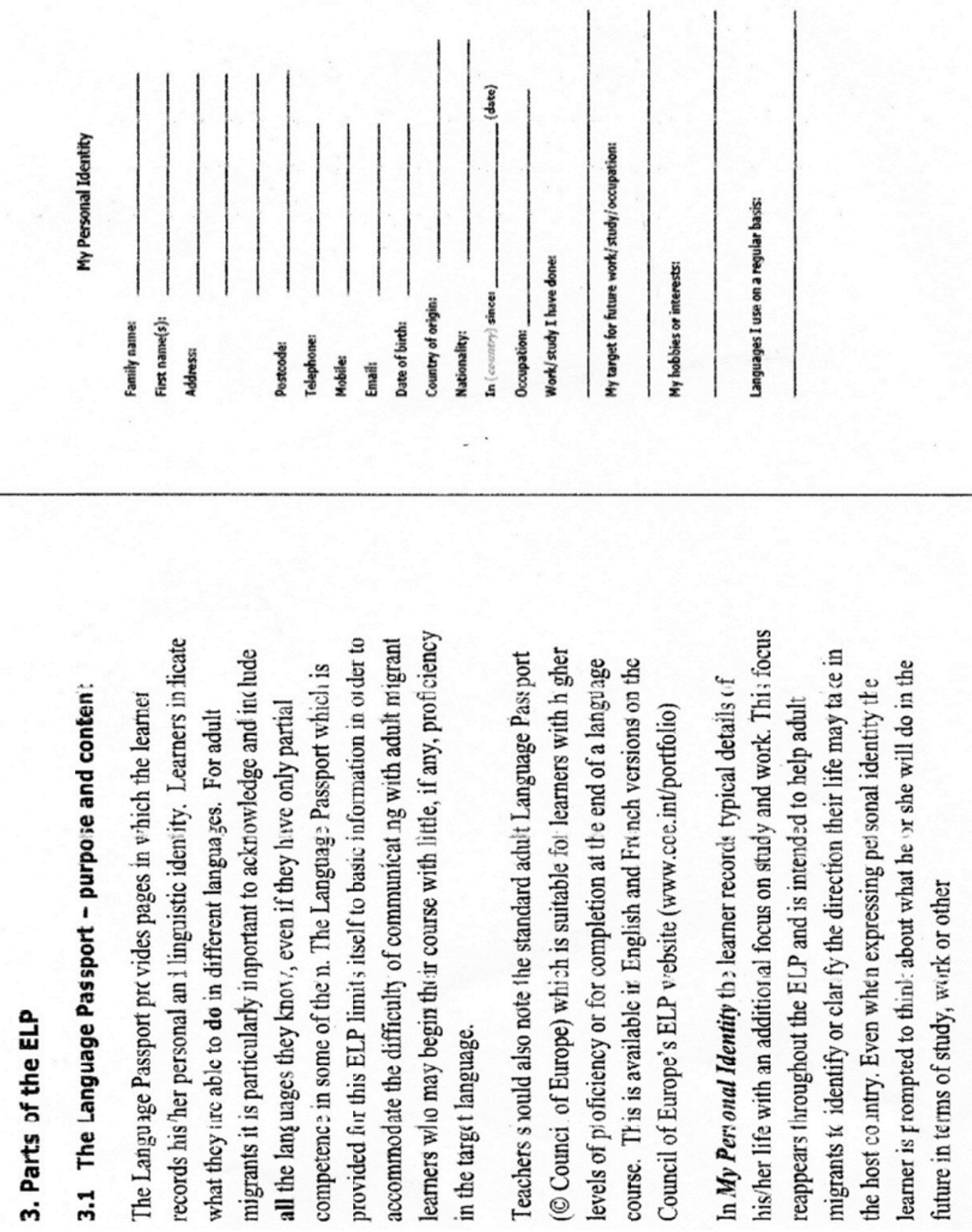
Appendix B.
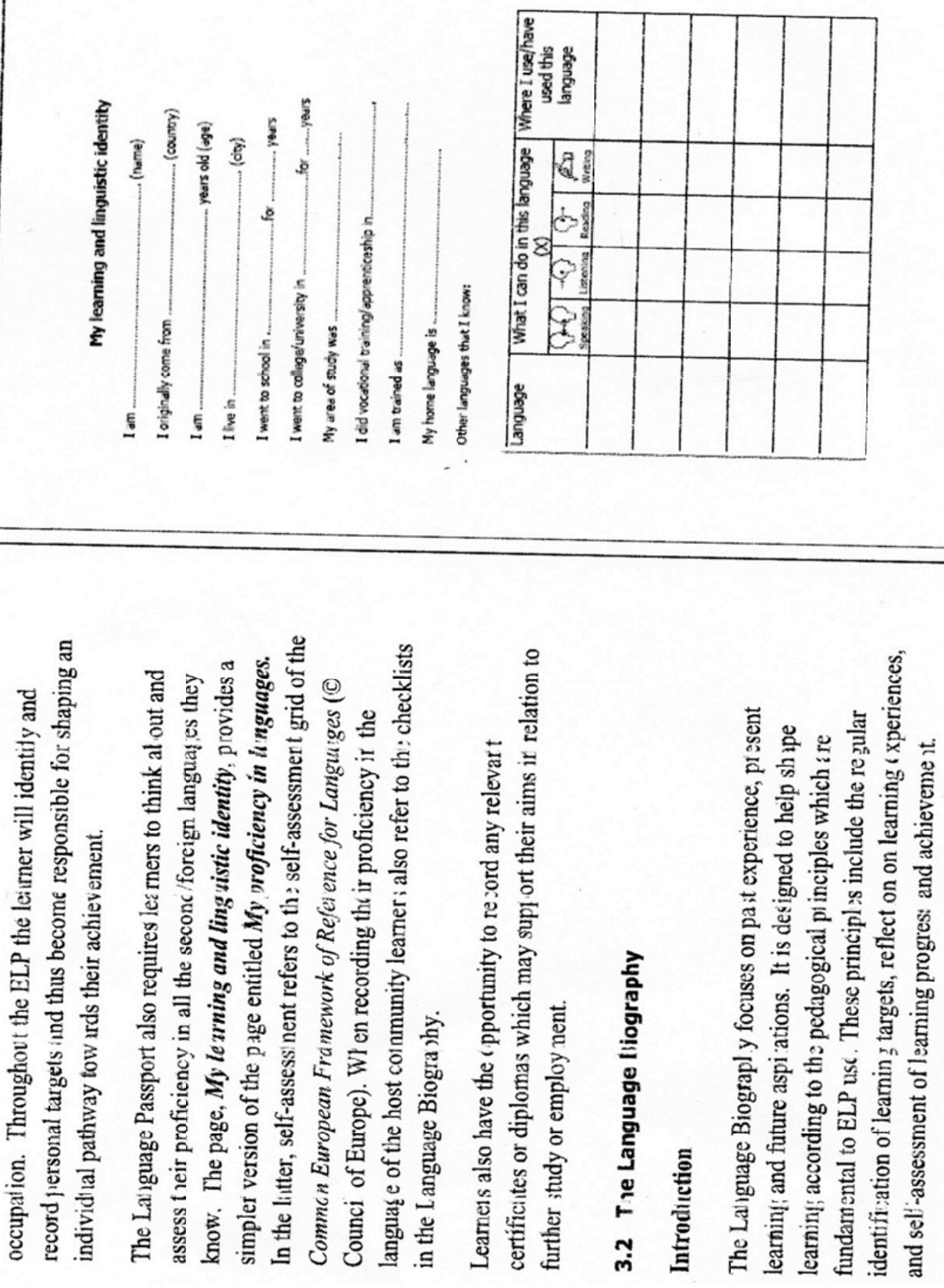
Appendix C.
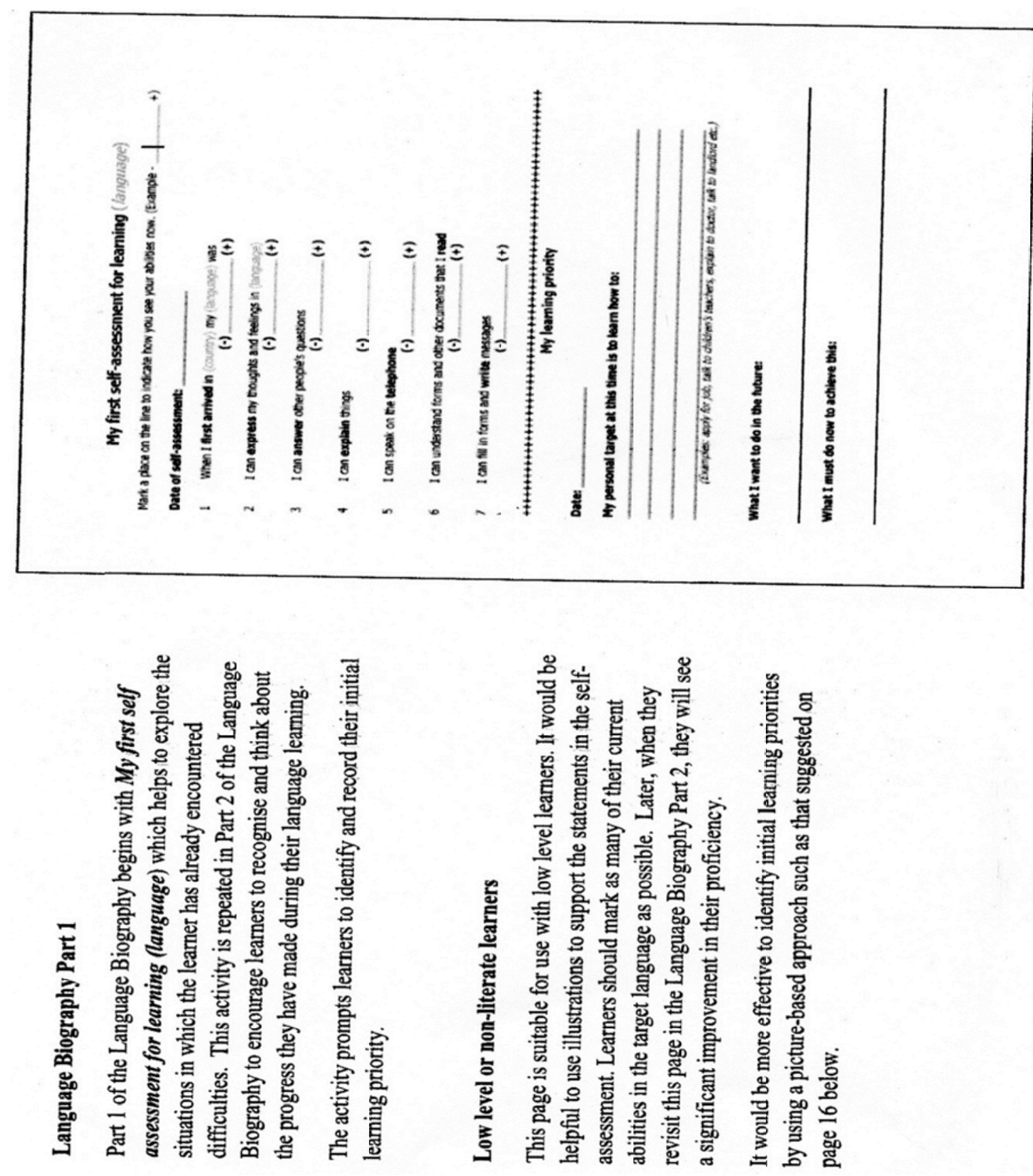
Appendix D.
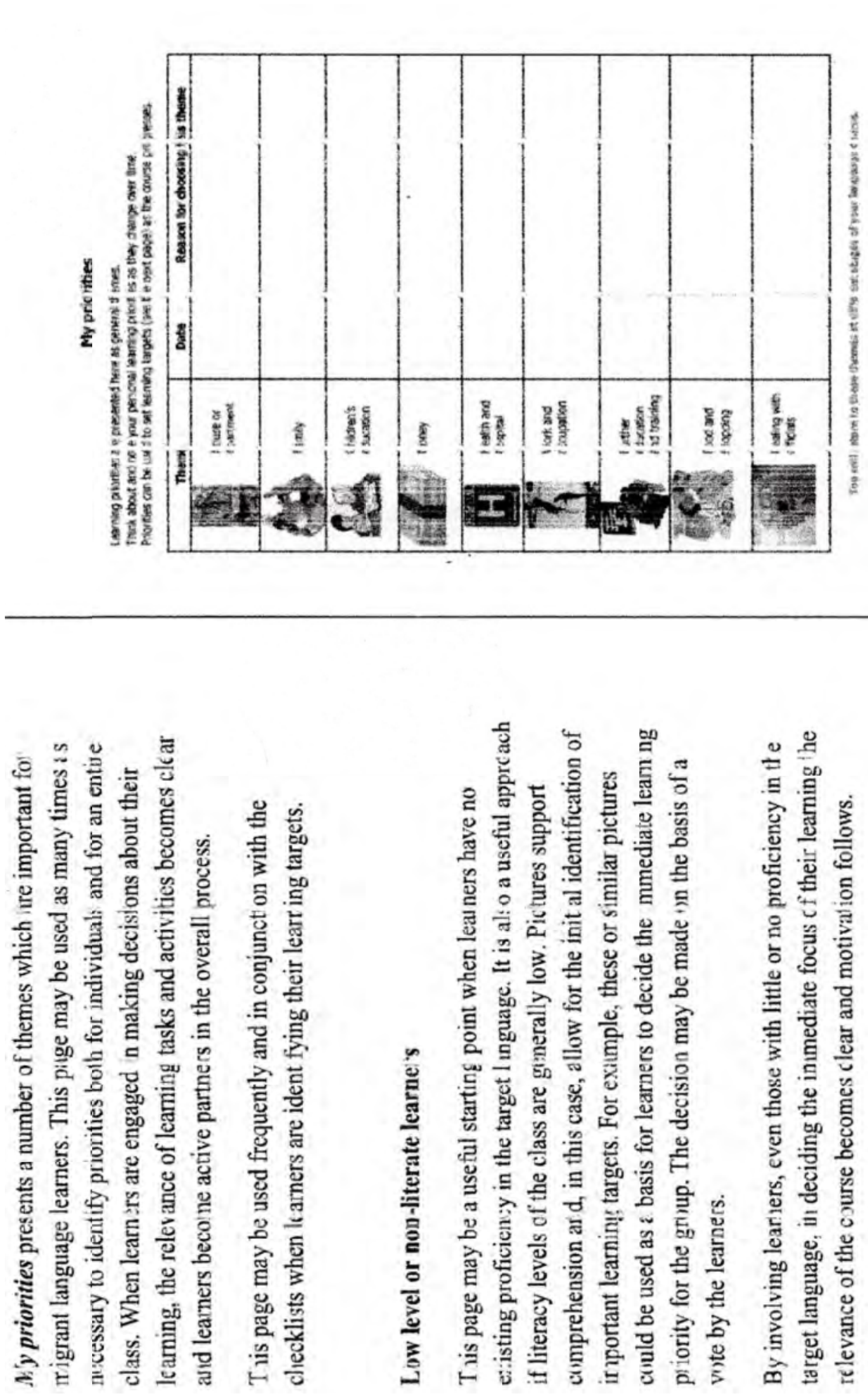
Appendix E.

\begin{tabular}{|c|c|c|c|c|c|}
\hline ป & 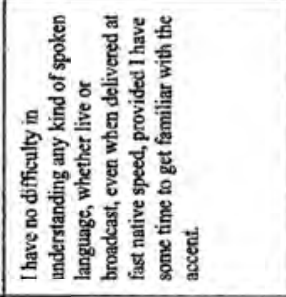 & 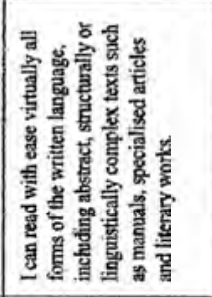 & 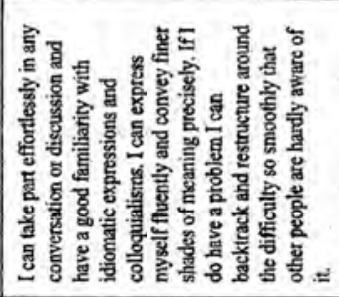 & 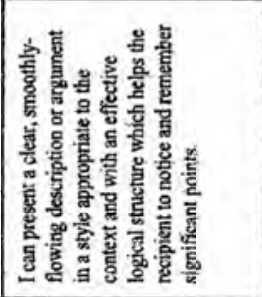 & 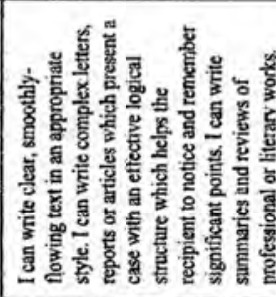 \\
\hline $\bar{U}$ & 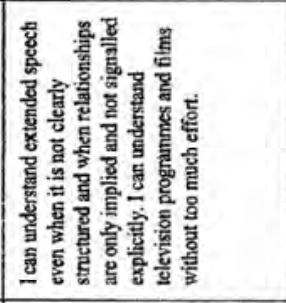 & 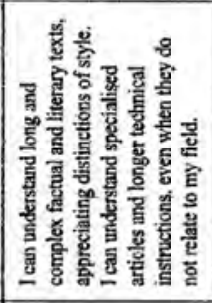 & 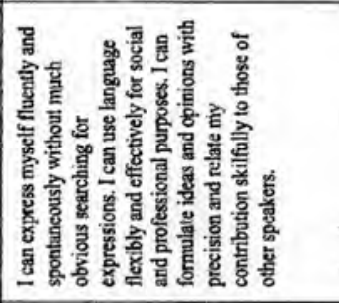 & 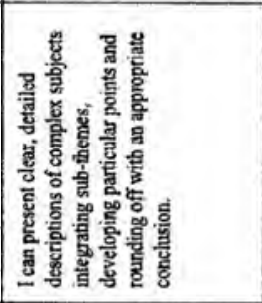 & 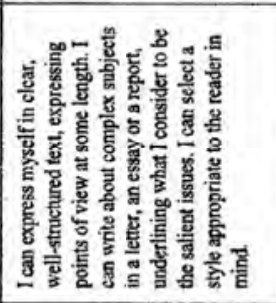 \\
\hline జ & 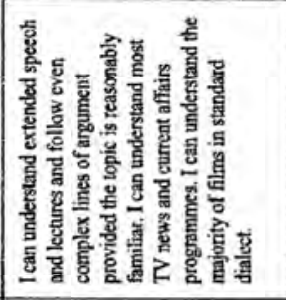 & 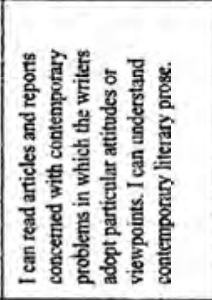 & 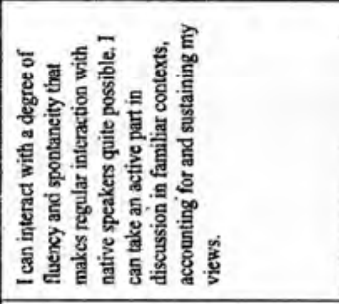 & 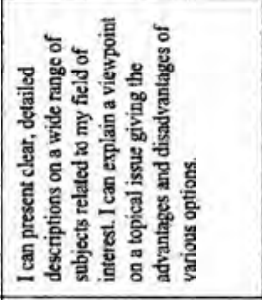 & 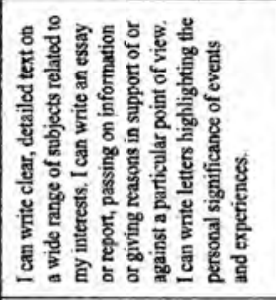 \\
\hline $\bar{\infty}$ & 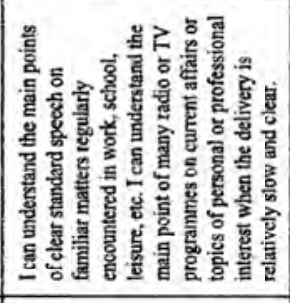 & 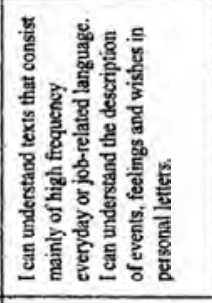 & 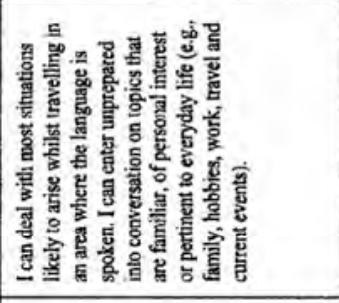 & 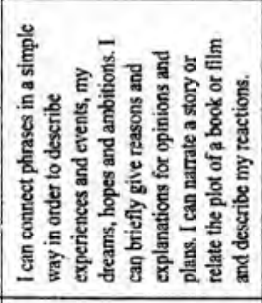 & 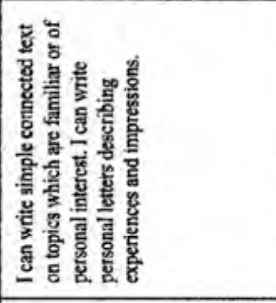 \\
\hline ₹ & 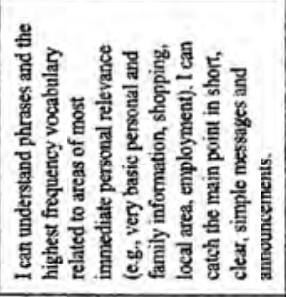 & 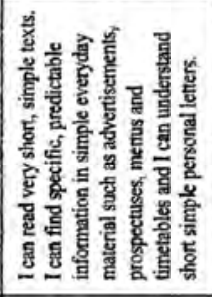 & 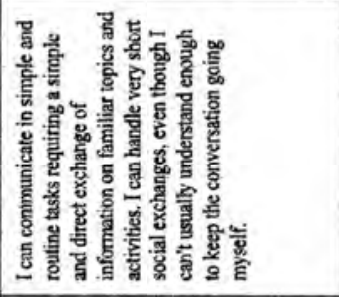 & 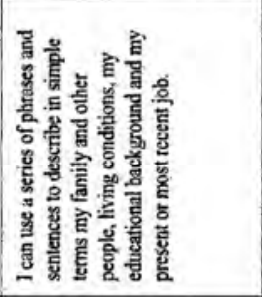 & 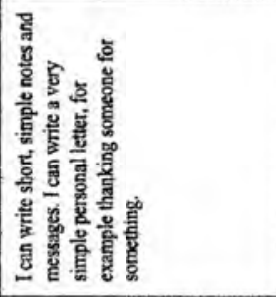 \\
\hline ₹ & 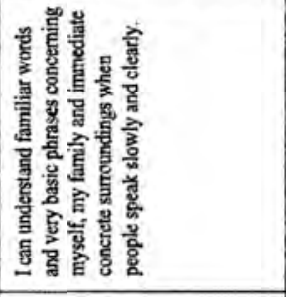 & 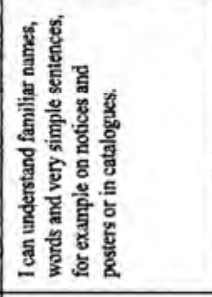 & 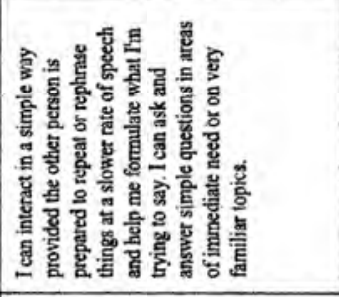 & 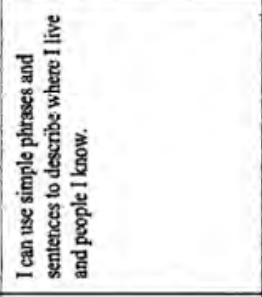 & 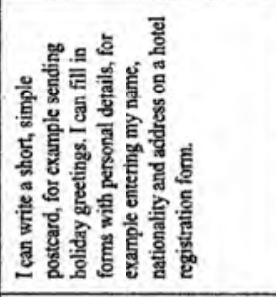 \\
\hline & $\begin{array}{l}\text { 递 } \\
\text { 惡 }\end{array}$ & 曾 & ह 흘 & 施 & 蛋 \\
\hline & \multicolumn{2}{|c|}{$D z a \Leftrightarrow \simeq n \in<a-z 0$} & \multicolumn{2}{|l|}{$n=\infty \times-z 0$} & $3 \times-1$ \\
\hline
\end{tabular}


Appendix F.

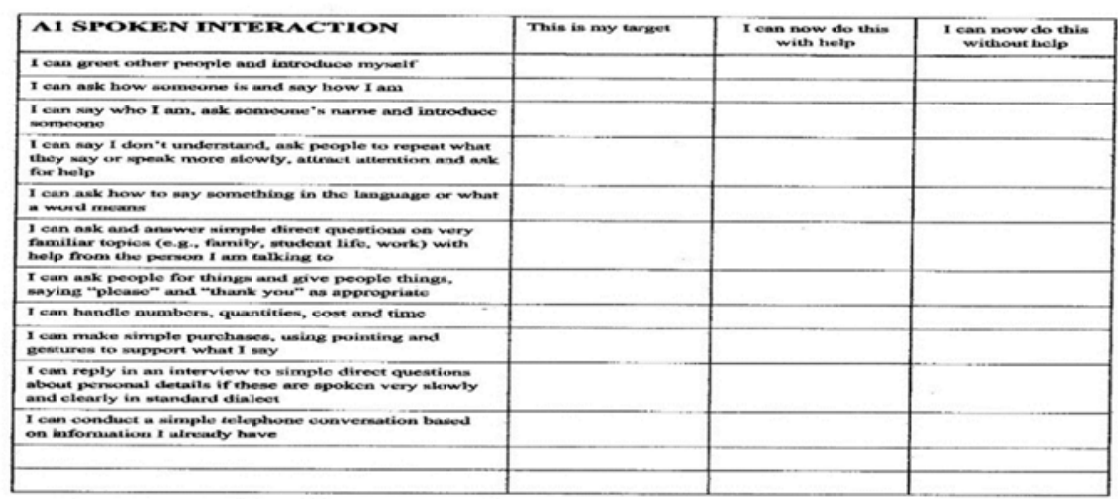

13

Cheeklists arranged by CEFR activity

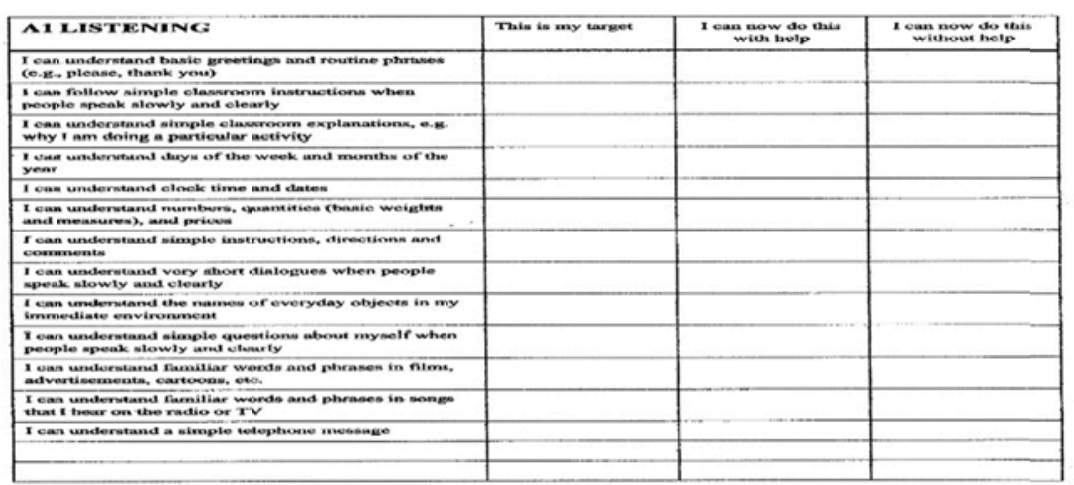


Appendix G.

\begin{tabular}{|c|c|c|c|}
\hline A2 SPOKKEN INTERACTYON & This is my ureat & 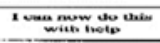 & 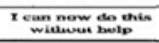 \\
\hline \multirow{2}{*}{\multicolumn{4}{|c|}{ 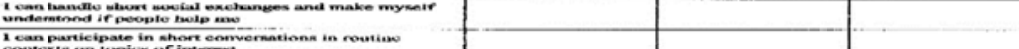 }} \\
\hline & & & \\
\hline \multicolumn{4}{|l|}{ 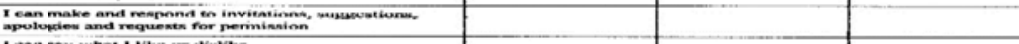 } \\
\hline \multicolumn{4}{|l|}{ 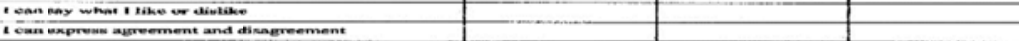 } \\
\hline \multicolumn{4}{|l|}{ 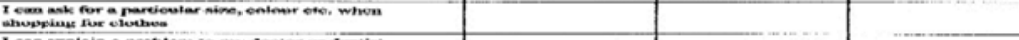 } \\
\hline \multirow{2}{*}{\multicolumn{4}{|c|}{ 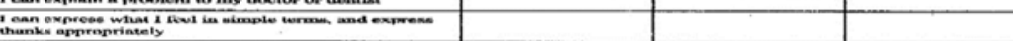 }} \\
\hline & & & \\
\hline \multicolumn{4}{|l|}{ 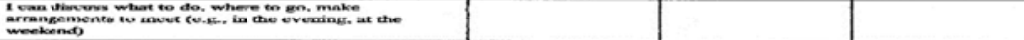 } \\
\hline \multicolumn{4}{|l|}{ A: } \\
\hline \multicolumn{4}{|l|}{ 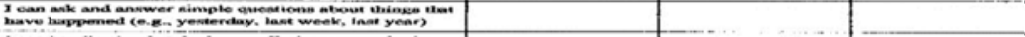 } \\
\hline \multicolumn{4}{|l|}{ 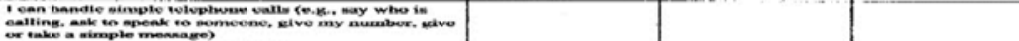 } \\
\hline \multicolumn{4}{|l|}{ 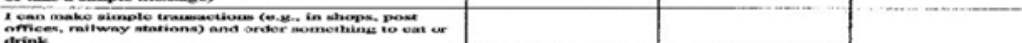 } \\
\hline 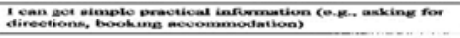 & & & \\
\hline & & & \\
\hline
\end{tabular}

14

\begin{tabular}{|c|c|c|c|}
\hline A2 L.NTERENG & This bo my tareet & 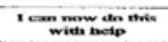 & Tean now do this \\
\hline \multicolumn{4}{|l|}{ 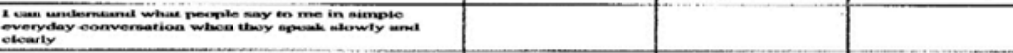 } \\
\hline \multicolumn{4}{|l|}{ 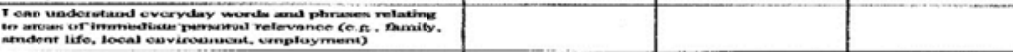 } \\
\hline \multicolumn{4}{|l|}{ 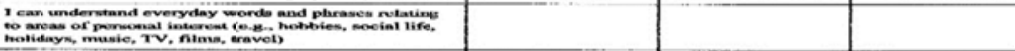 } \\
\hline \multicolumn{4}{|l|}{ 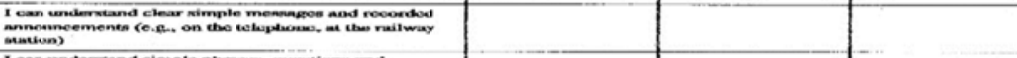 } \\
\hline \multicolumn{4}{|l|}{ 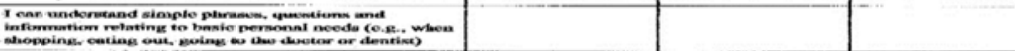 } \\
\hline \multicolumn{4}{|l|}{ 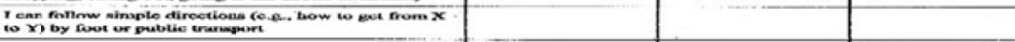 } \\
\hline \multicolumn{4}{|l|}{ 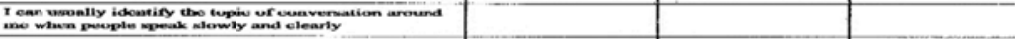 } \\
\hline \multicolumn{4}{|l|}{ 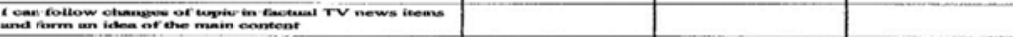 } \\
\hline \multicolumn{4}{|l|}{ 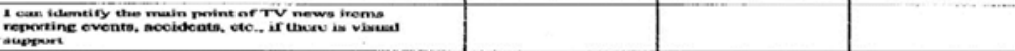 } \\
\hline \multicolumn{4}{|l|}{ 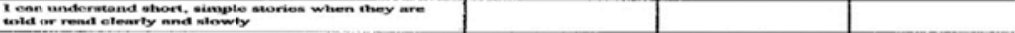 } \\
\hline \multicolumn{4}{|l|}{ 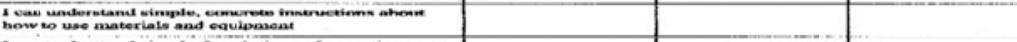 } \\
\hline \multicolumn{4}{|l|}{ 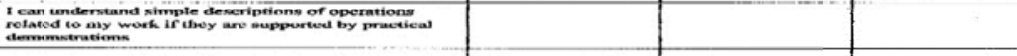 } \\
\hline 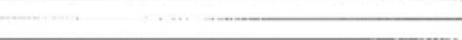 & & & \\
\hline
\end{tabular}

\section{Copyrights}

Copyright for this article is retained by the author, with first publication rights granted to the journal.

This is an open-access article distributed under the terms and conditions of the Creative Commons Attribution license (http://creativecommons.org/licenses/by/4.0/). 